\title{
Um pedido de perdão oficial e o Xangô Rezado Alto: apropriações da memória e estratégias retóricas no Centenário do Quebra de $1912^{1}$
}

\author{
An official request for forgiveness and Prayed out loud Shango: \\ appropriations of memory and rhetorical strategies at the Centenary \\ of the 1912 Shango riots
}

\author{
Ulisses N. Rafael \\ Universidade Federal de Sergipe, Brasil \\ ORCID iD: https://orcid.org/0000-0002-5339-917X \\ E-mail: ulisses38@gmail.com
}

Recepción: 2.05.2020

Aprobación: 18.08 .2020

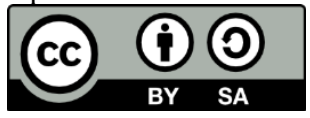

Resumo: Este artigo discute a relação entre a política e a religião no contexto específico do evento denominado Xangô Rezado Alto, ocorrido em Maceió (AL) em fevereiro de 2012, para marcar os cem anos do acontecimento dramático que ficou conhecido no local como o "Quebra de 1912", o qual, por sua vez, consistiu na invasão das principais casas de culto de matriz africana no estado alagoano. A celebração do centenário da "Operação xangô" outro nome pelo qual ficou conhecida a devassa aos terreiros afro-alagoanos em 1912, começou com cortejo realizado por integrantes dos principais terreiros locais pelas ruas centrais de Maceió e culminou com o "pedido de perdão oficial", protagonizado pelo então governador do estado.

A comemoração teve impacto imediato sobre as comunidades de santo envolvidas na celebração, dada a visibilidade pública obtida por seus participantes durante a realização do cortejo e em todas

\footnotetext{
${ }^{1}$ Versão preliminar deste texto foi apresentada na IV Semana de Antropologia do PPGA/UFPB, ocorrida em João Pessoa em 2018. Agradeço pelo convite realizado por Luciana Chianca (PPGA/UFPB), coordenadora da Mesa Redonda: Antropologia e cidadania: éticas, moralidades, justiças; agradeço também pelo vívido interesse demonstrado pelas outras duas participantes da Mesa, as professoras Luciana Carvalho (UFOPA) e Lady Selma Albernaz (UFPE), quem também leu e fez anotações sobre esta versão escrita.
} 
as demais atividades que integraram a programação do evento, porém, durante a realização das comemorações o ato oficial promovido pelo governador ocupa posição destacada nos ritos da celebração. Este ponto de vista é aqui defendido através das narrativas impressas e imagéticas produzidas por ocasião desse evento.

Palavras-chave: cultos afro-brasileiros, "Operação Xangô", "Xangô rezado Alto", estado.

\begin{abstract}
This article argues about the relationship between politics and religion in the specific context of the event called Prayed out Loud Xangô, which took place in Maceió (AL), in February 2012, to mark the one hundred year anniversary of the dramatic event that became known in the city as the "1912 riots", which, in turn, consisted of the invasion of the main Xangô terreiros, places of the African matrix cult, in that state. The celebration of the centenary of "Operation Xangô", another name by which the wanton destruction of Xangô terreiros also became known, started with a procession carried out by members of the main local terreiros through the central streets of Maceió city and finished with the "request of official pardon", led by the then governor of the state.

The celebration had an immediate impact on comunidades de santo ("communities of saint") involved in the celebration, due to the public visibility obtained by its members during the procession and in all other activities that were integrated into the event's program. However, during the celebrations, the official act promoted by the governor occupies a prominent position in the celebratory rites. This point of view is defended here, through news from printed newspapers and imagery narratives produced during the event.
\end{abstract}

Keywords: Afro-Brazilian cults, Xango Operation, Prayed out Loud Xangô, state.

INTRODUÇÃO

O presente artigo trata da relação entre a política e a religião no contexto específico do evento denominado Xangô Rezado Alto ocorrido em Maceió (AL), nos dias 1 e 2 de fevereiro de 2012, para marcar os cem anos de outro acontecimento dramático, o Quebra de 1912, que consistiu na invasão das principais casas de culto de matriz africana no estado alagoano. A celebração do centenário do Quebra de 1912 começou com cortejo realizado por integrantes dos principais terreiros locais pelas ruas centrais de Maceió e culminou com a realização da solenidade do "pedido de perdão oficial", protagonizado pelo então governador do estado, Teotônio Vilela Filho.

A comemoração teve impacto imediato sobre as comunidades de santo envolvidas na celebração, dada a visibilidade pública obtida por seus participantes durante a realização do cortejo e em todas as demais atividades que compunham a programação do evento. Do ponto de vista legal, o ato oficial promovido pela autoridade máxima do executivo reforçou a legitimidade das práticas religiosas de presença africana no estado e possibilitou o resgate da memória ancestral das comunidades tradicionais de cultos afro-alagoanos, as quais, por muito tempo, estiveram relegadas ao silêncio. 
Contudo, para além do alcance político do Xangô Rezado Alto e, sobretudo, das vantagens simbólicas obtidas pelo povo de santo, cumpre destacar o contraditório e súbito protagonismo assumido pelo governador na celebração, quando ocupou posição destacada, tal como se pode depreender das narrativas produzidas por ocasião do evento, objeto deste trabalho.

Neste artigo, portanto, analisarei as matérias jornalísticas publicadas no Diário Oficial, principal órgão do executivo estadual, e as imagens veiculadas no periódico Gazeta de Alagoas. As retóricas aí contidas permitem observar as estratégias políticas do representante máximo do estado, cuja atuação sobrepõe-se às ações das próprias comunidades de santo e sua história de opressão e silenciamento, verdadeiro objeto da celebração.

\section{PolíticA E RELIGĨ̃o}

A relação entre política e religião no Brasil é sobejamente conhecida e tem sido objeto de vívido interesse por parte de inúmeros estudiosos, principalmente, dos pesquisadores da religiosidade afro-brasileira. Fry e Maggie (2006), por exemplo, remontam o debate sobre o assunto às contribuições de Nina Rodrigues, considerado fundador da antropologia brasileira. Entre os temas tratados pelo médico maranhense em $O$ animismo fetichista dos negros baianos (2006) destaca-se a atenção dispensada à "generalização das crenças africanas na sociedade baiana, inclusive na sua elite" (Fry \& Maggie, 2006, p. 11), como se pode depreender das palavras do próprio Nina:

A mola é sempre o interesse eleitoral, que neste país faz de tudo catavento e nas grandes influências políticas vão eles buscar os seus melhores protetores. Sei de um senador e chefe político local que se tem constituído protetor-chefe dos ougans e pais de terreiro. E acrescente-se aos interesses materiais e diretos a crença supersticiosa nas práticas fetichistas por parte de pessoas influentes, e poder-se-á fazer uma ideia do grau de proteção indireta de que hoje podem dispor os feiticeiros. (Rodrigues, 2006, p. 55)

João do Rio, apesar de eminentemente jornalista, vai também se tornar uma das maiores autoridades sobre as religiões brasileiras de origem africana no começo do século XX. Seu livro As religiões do Rio (do Rio, 1906) está repleto de passagens nas quais destaca o fascínio - ou o "vício" - que as chamadas "religiões africanas" exerciam sobre toda a sociedade brasileira: "Vivemos na dependência do feitiço... somos nós que lhe asseguramos a existência com o carinho de um negociante por uma amante atriz..." (do Rio, 1906, p. 35).

Entre as particularidades do episódio denominado Quebra de 1912, consta o fato de o governador Euclides Malta ter sido acusado de manter relações 
nada republicanas com os cultos de matriz africana, tendo, inclusive, recorrido aos terreiros da capital para se manter no poder por mais tempo.

A crônica jornalista alagoana da época informa que, no auge da crise política que decidiria os rumos políticos do estado, "não se podia dormir sossegado em certas ruas de Maceió, devido ao barulho dos tambores e dos zabumbas, nos terreiros..." (Lima Júnior, 2001, p. 154). Por esse motivo, a população, enfurecida e indignada com os desmandos administrativos do governador, invadiu e destruiu as principais casas de Xangô de Maceió, logo após Euclides Malta ter sido apeado do poder. Esse é o episódio que, 100 anos depois, seria rememorado no evento denominado Xangô Rezado Alto, e que aqui me proponho a analisar.

\section{A OPERAÇÃO XANGÔ}

Nos últimos anos, têm sido explorados vários aspectos relacionados ao episódio da Operação Xangô - outro nome pelo qual ficou conhecido o Quebra dos Terreiros de 1912. Os primeiros resultados desses estudos foram publicados no livro intitulado Xangô Rezado Baixo (Rafael, 2012). Essa expressão foi tomada de empréstimo do médico pernambucano Gonçalves Fernandes, que a forjou quando de sua visita aos terreiros de Maceió na década de 1930. Na capital alagoana, o especialista em religiões de presença africana localizou essa modalidade de culto, a qual também denominou de "candomblé em silêncio" em razão do aspecto reservado e fechado das cerimônias religiosas ali localizadas, destituídas de todo o aparato visual e do uso dos atabaques (Fernandes, 1941, pp. 9-10).

O próprio evento aqui analisado, denominado Xangô Rezado Alto, também decorre de uma reapropriação da expressão cunhada por Fernandes, embora agora a ressignificando positivamente em favor da memória histórica dos terreiros alagoanos. Adiante, voltarei a tratar especificamente desse episódio mais recente. Por ora, talvez se faça mais necessário informar o que foi, afinal, o tão propalado Quebra de 1912.

O evento assim conhecido consistiu numa ação coordenada por integrantes da Liga dos Republicanos Combatentes, misto de guarda civil e milícia particular, surgida em Maceió em novembro de 1911 para fornecer suporte à campanha difamatória contra Euclides Malta durante processo eleitoral que escolheria seu sucessor. Contudo, o governador seria, antes, destituído. Entre outros motivos mais fortes apresentados pela imprensa da época, estaria o fato de o mandatário máximo do estado alagoano ser acusado de envolvimento com as casas de culto de presença africana, onde, segundo seus oponentes, ia buscar proteção para se 
manter por mais tempo no poder. No curto intervalo em que esteve afastado das funções administrativas, a população enfurecida investiu também contra os integrantes dos terreiros da capital, seus supostos aliados (Rafael, 2012).

Esses atos contra as religiões afro-brasileiras, os mais violentos contra essa modalidade de culto na história de Alagoas, provocaram a fuga de pais, mães e filhos de santo para os vizinhos estados da Bahia e de Pernambuco, para escapar do regime de intolerância religiosa que se instalou após o fim da Era dos Maltas². Os objetos que sobreviveram à invasão das antigas casas foram conduzidos à sede da Liga dos Republicanos Combatentes, também residência do seu fundador, Manoel Luiz da Paz, na antiga rua do Sopapo, no mesmo bairro da Levada, onde se iniciara a devassa. Ali os despojos ficariam em exposição até serem transferidos para sede da Sociedade Perseverança e Auxílio dos Caixeiros de Maceió, antiga associação dos empregados do comércio, e cujo museu "seria enriquecido" com os objetos dos cultos afro-brasileiros "salvos" do ataque e da destruição dos xangôs da capital (Barros, 2005):

Ante-hontem [05/02/1912] fômos completar as nossas informações na exposição que se fez na sède da "Liga dos Republicanos Combatentes". A sala da "Liga" estava transformada em museu e tinha o aspecto alegre de um presepe em noite de natal. Tudo muito bem arrumado e espalhadas pelo chão algumas gamelas com um "santo" (uma pedra) mergulhado em azeite Um "filho de santo" desses muitos que ali foram contemplar os preciosos despojos, tudo explicou e a "Liga" fez escrever em pedacinhos de papel os diversos mysterios daquela alluvião de bugingangas. (Prato do dia, 1912, p. 1) ${ }^{3}$

Um importante registro dessa exposição foi localizado na revista carioca O Malho, em matéria intitulada "Feitiçaria official protetora das oligarchias". Alista-se, aí, o recebimento de duas fotografias enviadas por outro jornal alagoano, $O$ Combatente, que circulou em Maceió entre setembro e dezembro de 1914 e cujo significado político advém do fato de ter sido o órgão oficial da Liga dos Republicanos Combatentes:

Recebemos de Maceió, a bella adiantada capital do Estado de Alagoas, officio que em seguida publicamos, acompanhado de interessantíssimo cliché. Um e outro prendem-se ao facto vergonhoso da feitiçaria política, senão instituída, pelo menos escandalosamente protegida pela gente do Senhor Euclydes Malta, a ponto de haver Changôs legalmente licenciados pela polícia, com impostos pagos, sobre o documento officiaes... Essas casas de bruxaria pullulavam por Maceió, como por aqui pullulam as casas do jogo do bicho, e entre ellas havia uma, a principal, que um bello dia foi invadida e varejada por mais de quinhentos populares, sendo aprehendidos os objetos que o leitor aqui Vera e que servi-

\footnotetext{
${ }^{2}$ Nome pelo qual ficou conhecido o longo período político dominado pela família Malta, que compreende os três mandatos de Euclides Malta como governador (1900/1903, 1906/1909 e 1909/1912), e o mandato intermediário cumprido por seu irmão Joaquim Vieira Malta (1903 e 1906).

${ }^{3}$ As citações referentes à cobertura do Quebra de 1912 foram mantidas em português antigo.
} 
ram no culto diário para a conservação do referido Malta no poder. Temos em nosso poder outros documentos; mas por hoje basta o que segue: "Secretaria do Movimento e Ordem da 'Liga dos Republicanos Combatentes' em Homenagem a Miguel Omena, Maceió, 19 de fevereiro de 1912. (Feitiçaria oficial protetora das oligarquias, 1912, p. 38)

Além da violência com que os objetos rituais foram recolhidos e da forma zombeteira como foram expostos à visitação pública nos dias seguintes à devassa, destaco, também, o fato de que, por muitos anos depois, aquelas práticas religiosas de presença africana foram submetidas a um profundo silenciamento, que também se abateu sobre outras modalidades artístico culturais de caráter profano a elas associadas, como o maracatu e o afoxé. Foi para rememorar esse silenciamento que o Xangô Rezado Alto, em 2012, realizou-se. Tratarei do assunto na sequência.

\section{O XANGÔ REZADO ALTO}

Como já dito, o Xangô Rezado Alto consistiu em um cortejo religioso realizado no dia 1 de fevereiro de 2012, reunindo as mais expressivas denominações de matriz africana de Maceió. O cortejo percorreu as principais ruas da capital até desembocar na Praça dos Martírios, epicentro simbólico e real do poder político local. O desfile culminou com o solene "pedido de perdão", por parte do governador do estado, às entidades presentes, pelo centenário e violento episódio que atingiu os principais terreiros de Xangô de Maceió e de cidades circunvizinhas em 1912.

O primeiro evento idealizado para celebrar a memória do Quebra de 1912 ocorreu em fevereiro de 2006, na Praça 13 de maio, no bairro do Poço. As informações sobre essa celebração foram encontradas em Fonseca (2020), a quem chama a atenção a presença naquele logradouro da escultura "de uma negra em concreto em cima de um pedestal [...]. Apresentada com vestes brancas compostas por vestido e touca [...(e)], uma criança branca em seus braços. [...] tratava (se) de uma Preta-Velha, entidade espiritual dos terreiros de Umbanda..." (Fonseca, 2020, pp. 18-19). Na estátua, havia ainda uma placa indicando se tratar de homenagem à "Mãe Preta", prestada pelo então prefeito Divaldo Suruagy (1965-1970) em nome do povo maceioense ${ }^{4}$.

\footnotetext{
${ }^{4}$ Curioso notar que o nome de Suruagy já constara em depoimento de uma mãe de santo entrevistada durante pesquisa de campo anterior em Maceió, que informou ter sido seu terreiro usualmente buscado por políticos alagoanos, principalmente em período eleitoral. Mais um reforço no argumento da relação intrínseca entre política e religião no Brasil. No caso específico de Suruagy, ele teria procurado a mãe de santo para consultas religiosas, inclusive no tempo em que ela ainda morava no bairro do Poço, o que talvez justifique a homenagem feita pelo então prefeito de Maceió naquele período e local específicos (cf. Rafael, 2012).
} 
Talvez porque dotada de pelo menos duas referências significativas para a história e a cultura negra como um todo é que a praça 13 de maio, com a presença do monumento em homenagem à "Mãe Preta", tenha sido escolhida para a realização da concentração do primeiro Xangô Rezado Alto. Tal justificativa, no entanto, não foi explorada por Fonseca (2020), que também não discute as razões pelas quais a celebração só seria retomada seis anos depois, na edição centenária que descreverei a seguir.

A cerimônia de 2012 esteve envolta em uma série de aspectos significativos, a começar pelo trajeto, escolhido para se iniciar na Praça D. Pedro II, também conhecida como Praça da Catedral, marco zero da capital. A escolha desse lugar remete à memória da escravidão, por ter existido ali, no passado, um pelourinho. O curto itinerário compreendeu a rua do Sol, que conecta o local de concentração dos participantes com a outra praça, a dos Martírios, situada no outro extremo da via, e para onde convergiu o conjunto das atividades culturais programadas para os dias $1^{\circ}$ e 2 de fevereiro. Durante o percurso, o cortejo parou diante de dois monumentos que também remontam à história do povo negro em Maceió: a igreja de Nossa Senhora do Rosário dos Pretos, cuja irmandade teve seu estatuto aprovado em 1830; e o Instituto Histórico de Alagoas, associação civil dedicada à pesquisa no estado e sobre a qual incidiu a responsabilidade de tutela e salvaguarda da Coleção Perseverança, formada pelos despojos da Operação Xangô ${ }^{5}$. Trata-se, portanto, da área urbana de maior centralidade na capital, o núcleo originário da cidade, e espaço pleno de memórias e sentidos, que naquela ocasião foram reapropriados ${ }^{6}$.

Assim como o evento de 2006, o de 2012 também foi idealizado pelos professores Edson Bezerra e Clébio Araújo, da Universidade Estadual de Alagoas, instituição que teve atuação preponderante na realização do último Xangô Rezado Alto, inclusive como responsável pela captação de parte dos recursos necessários junto ao Ministério da Cultura do Governo Federal, na ordem de $\mathrm{R} \$ 250$ mil reais. O executivo estadual contribuiu com o aporte de $10 \%$ do orçamento e com o "perdão oficial". A atenção aqui se dedica mais amiúde sobre a participação desta última instância oficial e burocrática e sobre o modo como sua presença ali repercute nos órgãos da imprensa local, setor responsável pelas "persuasões retóricas" que nos interessam mais particularmente ${ }^{7}$.

\footnotetext{
${ }^{5}$ A Coleção Perseverança encontra-se fartamente analisada em Rafael (2015), embora o registro pioneiro tenha sido feito por Duarte (1974).

${ }^{6}$ Sobre a ideia de centralidade urbana, conferir Pesavento (2008).

${ }^{7}$ A expressão "persuasões retóricas" inspira-se nas contribuições de Marilyn Strathern, que substitui o termo ficção, quando quer se referir à apresentação dos fatos, alterando-os ou distorcendo-os,
} 


\section{AS RETÓRICAS NA IMPRENSA}

Neste tópico, destaco o papel que a imprensa desempenhou nos dois momentos históricos que marcaram, por um lado, a revolta popular que culminou com a violência contra os terreiros de matriz africana em Maceió, em 1912, e, por outro, a rememoração desse mesmo episódio, ocorrida cem anos depois.

No contexto que envolveu o Quebra de 1912, tanto os grupos religiosos afro-alagoanos como o representante máximo do executivo foram completamente rechaçados pela imprensa local - e até nacional - por suposto conluio religioso, sobretudo no período em que o governador se encontrava afastado do poder e do estado. No auge da campanha eleitoral que escolheria seu substituto, Euclides Malta vinha sofrendo inúmeras acusações, entre as quais, a que mais efeito teve sobre a população revoltosa parece ter sido a de que os terreiros de xangô da capital lhe davam proteção e rezavam para sua permanência no poder por longo tempo. Subjacente a esse ataque, pairava a noção, entre os jornalistas alagoanos, de que a "bruxaria" representava o que havia de mais atrasado na cultura local, cujos rudes costumes precisavam ser duramente repelidos tanto quanto as oligarquias que os favoreciam:

Sabia se que entre o nefasto governo do sr. Euclides Malta e as inumeras casas de feitiçaria barata, profusamente espalhadas pela cidade, existia a mais estreita afinidade. Sabiase que a grande força em que o inepto oligarcha apoiava o seu governo era o "xangô", e com essa confiança de fetiche ignorante mantinha em completa desorganização a sua policia e em completa debandada todos os outros poderes organicos do Estado, locupletando-se manhosamente do preto de uma centena de praças, que nunca existiram, em proveito dessas casas, que a policia devia antes destruir para socego e moralidade dos habitantes desta cidade. (Bruxaria, 1912, p. 1)

Situação distinta da atualidade do Xangô Rezado Alto, quando representantes do Poder Executivo, sobretudo o governador Teotônio Vilela Filho, e integrantes dos grupos religiosos de presença africana figuraram na imprensa lado a lado para sancionar o "pedido oficial de perdão" e firmar pacto definitivo de tolerância às comunidades de terreiro de Alagoas. Interessa-me, pois, acompanhar, agora, as narrativas midiáticas desse último evento e as retóricas persuasivas a ele subjacentes.

em razão das vantagens obtidas pelo efeito pessoal e particular. Segundo a autora, o que se deve levar em conta é "o efeito surpreendente de aceitação imediata [e] em larga escala [dessas retóricas]" (Strathern, 2013, p. 160). 
Boa parte do material utilizado nesta análise encontra-se no Diário Oficial de Alagoas, que, entre os dias 25 de janeiro e 2 de fevereiro de 2012, publicou em seu suplemento a série "100 anos do Quebra de Xangô":

A universidade Estadual de Alagoas (UNEAL) - em parceria com a Secretaria de Estado da Mulher e Cidadania e dos Direitos Humanos - promove nos dias 1 e 2 de fevereiro, uma série de atividades para lembrar o Quebra de Xangô de 1912, evento que marcou a história de perseguição aos adeptos de religiões de matriz africana. A programação ocorrerá na Praça dos Martírios, em Maceió, mesma cidade que sediou os fatos hediondos contra a cultura negra há cem anos. (Soares \& Simões, 2012, p. 7)

Convém notar que o papel cumprido atualmente pelo Diário Oficial de Alagoas era desempenhado antes pelo jornal A Tribuna, órgão responsável pela publicação tanto do expediente do Estado quanto do Partido Republicano Federal de Alagoas, não por acaso, presidido por Euclides Malta. Curiosamente, o próprio maquinário d'A tribuna seria adquirido pelo então governador do estado para compor as oficinas do novo órgão governativo, o Diário Oficial, que começa a circular em 1912, no auge da campanha política que contra ele se desenvolveu (de Sant'Ana, 1987). Cem anos depois, coube ao mesmo Diário produzir as narrativas celebrativas do Xangô Rezado Alto, as quais têm início com o registro da reunião que firmaria o pacto em torno da solenidade futura:

Em reunião, na segunda-feira (23), no Palácio República dos Palmares, o governador Teotônio Vilela Filho comprometeu-se a assinar, no dia 1 de fevereiro, durante a programação do projeto Xangô Rezado Alto, um ato público de pedido oficial de perdão do Governador do Estado às comunidades de terreiro e a todo o povo de Alagoas pelas atrocidades cometidas em 1912. (Soares \& Simões, 2012, p. 7)

Na edição do dia 31 de janeiro de 2012, o projeto é estampado na primeira página do suplemento; no interior da publicação, encontra-se o detalhamento da manchete, em que se ratifica o ato oficial que ocorreria no dia seguinte e expõese a programação:

O governador Teotônio Vilela Filho assinará, nesta quarta-feira $\left(1^{\circ}\right)$, às $17 \mathrm{~h} 30$, um pedido de perdão oficial do Governo de Alagoas a todas as comunidades de terreiros de alagoas pelas atrocidades que marcaram o dia $1^{\circ}$ de fevereiro de 1912 , conhecido como o Quebra do Xangô ou Quebra de 1912. A assinatura se dará no final do cortejo popular, marcado para sair às $15 \mathrm{~h}$ da Praça D. Pedro II, pela Rua do Sol até a Praça dos Martírios, trecho considerado importante ponto de confluência de terreiros de Maceió. (Simões, 2012, p. 6)

Finalmente, no dia 1 de fevereiro, por meio do Decreto 18.041, o governador formaliza o pedido de perdão à população afro-alagoana e à religiosidade afro-brasileira pelos atos praticados contra tais segmentos na ocasião do episódio histórico denominado Quebra dos Xangôs de 1912. O ato foi largamente registrado na edição do suplemento do dia 2 de fevereiro, inclusive estampando na 
capa a foto do governador ladeado pelo reitor da UNEAL, Jairo Campos, e por Mãe Miriam, a mãe de santo mais antiga de Maceió. A cerimônia foi assim descrita em uma de suas passagens:

Após a passagem e revista às tropas ao lado do reitor da Uneal, Jairo Campos, e da Mãe Miriam, vice-presidente da Federação Zeladora das Religiões Afro-brasileiras em Alagoas, o governador Teotônio Vilela Filho, secretários de Estado e representantes das casas de candomblé formaram a frente de honra do evento. Em seu discurso, Teotônio saudou os alagoanos de todas as matrizes culturais, e afirmou que o momento era para reconhecer os horrores praticados contra estas religiões afros há exatos 100 anos. (Cabral, 2012, p. 3)

Interessante observar que, numa relação com o passado, diametralmente invertida, o Diário Oficial cumpre o papel oposto ao do Jornal de Alagoas, periódico através do qual reconstituí o momento político que implicou, em 1912, a expulsão de Euclides Malta do poder e a invasão das casas de culto de presença africana em Maceió. Em meio a toda crise política e social daquela época, o Jornal de Alagoas produz e fixa toda a narrativa válida e até hoje utilizada para a compreensão daquele período tão crítico da história do estado de Alagoas. A série de reportagens intitulada "Bruxaria" é o testemunho "oficioso" da invasão das mais de trinta casas de culto espalhadas pela capital, promovida com a participação de mais ou menos duas mil pessoas ${ }^{8}$.

Mais recentemente, foi o Diário Oficial que assumiu a narrativa, divulgando os preparativos do Xangô Rezado Alto, a assinatura do pedido de perdão e o discurso do Governador Teotônio Vilela Filho. Sem descuidar do significado histórico e simbólico que o ato oficial adquire em termos de visibilidade e de reconhecimento público alcançados na solenidade, na direção de comunidades que sempre estiveram à margem da vida social em qualquer local e tempo da nossa história, vou agora me deter sobre essa nova "escritura" para apontar algumas de suas aporias ou inconsistências internas ${ }^{9}$.

\section{A PERFORMANCE RITUAL DO PERDÃO ${ }^{10}$}

Para refletir sobre a apropriação da memória pelas instâncias oficiais do Estado, convém analisar as estratégias narrativas que despontam no desenvolvimento da comemoração do perdão, as quais têm um sentido distinto da rememo-

\footnotetext{
${ }^{8}$ O Jornal de Alagoas publicou entre os dias 2 e 10 de fevereiro de 1912 uma série de cinco matérias intituladas "Bruxaria", em que relata com detalhes etnográficos a destruição dos principais terreiros de xangô de Maceió e de cidades vizinhas.

${ }^{9}$ A ideia de aporia encontra-se amparada em Strathern (2002).

${ }^{10}$ A noção de performance que aqui utilizo se inspira nas assertivas de Victor Turner, que aplica o termo a uma ação simbólica mais frequentemente localizada em contextos culturais contemporâneos, ampliando, assim, a compreensão clássica de ritual de uso mais restrito (Turner, 1987).
} 
ração social do sofrimento, que é própria das comunidades de terreiro ${ }^{11}$. Assim sendo, há que se destacar no Xangô Rezado Alto, no conjunto de narrativas aparentemente simétricas, a realidade desigual que situa, de um lado, os segmentos mais diretamente afetados pelo infortúnio histórico do Quebra de 1912 e, do outro, a agência oficial do Estado envolvida também na organização da comemoração dos cem anos e cuja retórica termina por sobrepor-se às demais, pelo menos em termos do tipo de recursos materiais e digitais utilizados.

O discurso do Governador Teotônio Vilela, por exemplo, publicado no Diário Oficial, é indicador das estratégias acionadas. Ele começa saudando os presentes e homenageados com as seguintes palavras: "Minhas saudações aos alagoanos e alagoanas de todas as matrizes culturais e todos os matizes religiosos". E continua:

[...] nossa memória alagoana precisa ser revigorada com o resgaste de lembranças escondidas, erroneamente varridas para baixo do tapete de penumbra do silêncio. Não podemos esquecer que 2012 marca o centenário do auge do período de perseguição aos praticantes dos cultos afro-brasileiros em Alagoas, época de terror especialmente forte em Maceió, no episódio conhecido como a "Quebra dos Xangôs" ou simplesmente "Quebra".

Pegando pela palavra, estamos aqui reunidos para quebrar o silencio oficial que reinou durante décadas sobre os horrores daqueles acontecimentos que marcaram o ano de 1912. Muito me orgulha, na condição de governador deste Estado, saber-me protagonista [grifo nosso] deste ato da maior importância. Hoje, capitaneados pela Universidade Estadual de Alagoas e seus parceiros nos reunimos para um passar a limpo da história, promovendo a justa compreensão da violência e dos prejuízos causados não só aos religiosos de matriz africana, mas a todo o povo alagoano. (Vilela Filho, 2012, p. 6)

Nessas palavras, é possível observar a expressão daquilo que MichelRolph Trouillot (1995) chama de "investimento de poder", para se referir à atitude daqueles que, a exemplo do que aconteceu com a história haitiana e ao assim chamado "descobrimento" da América, determinaram o que pode ou não ser visto ou falado. O discurso do governador explicitamente atesta o sentido do fazer-se história de Trouillot (1995), quando se propõe passar a limpo a história. Ou seja, no evento selecionado, observei a utilização de uma retórica que, ao mesmo tempo em que retifica o papel do Estado, também o coloca como protagonista:

Assim, observando atentamente o ocorrido há um século, o Estado de Alagoas pede perdão pelo que seus Poderes Constituídos possam ter contribuído, por ações e/ou omissões, para com a violência desencadeada pelos obscurantistas da entidade civil conhecida como Liga dos Combatentes Republicanos e quem quer que lhe tenha sido cúmplice na vergonhosa onda de crimes cometidos contra os praticantes dos cultos afro-brasileiros. [...] Queremos virar essa página da história nos comprometendo com uma nova etapa, com o projeto

${ }^{11}$ Para uma melhor compreensão dos sentidos distintos entre comemoração e rememoração, conferir Silva (2002). 
de uma nova Alagoas, onde todos e todas possam exercer livremente suas diferenças e, a partir delas, garantir um futuro digno para seus filhos. (Vilela Filho, 2012, p. 6)

Trata-se, portanto, de uma performance ritual planejada nos mínimos detalhes e que tem sua culminância na cerimônia histórica divulgada como "pedido oficial de perdão". Evidentemente, não subestimo a mobilização por parte de inúmeros grupos locais em torno desse evento, o qual representa uma inestimável promoção da cultura negra em Alagoas e mais uma forma de combate à intolerância contra as religiões de matriz africana no estado. No campo propriamente religioso, observa-se o envolvimento da comunidade de santo de Maceió, cuja participação em eventos públicos locais vinha se revestindo de caráter cada vez mais político, sobretudo a partir de 2011, quando a Secretaria de Cultura do município quis restringir o tempo e o espaço das apresentações religiosas na festa de Iemanjá na Praia da Pajuçara ${ }^{12}$.

Contudo, a presença oficial do governador de Alagoas parece transbordar esse histórico de engajamento das associações negras de Maceió, na medida em que ele passa a ocupar o centro das atenções no momento mais crucial da celebração, deixando a impressão de que o evento como um todo foi cuidadosamente organizado para que a performance do perdão obtivesse essa ascendência sobre as demais performances. A confirmação dessa composição cerimonial pode ser obtida por meio das imagens produzidas e publicadas na imprensa local. O Diário Oficial, por exemplo, ilustra bem o peso do espetáculo, estampando na capa do suplemento comemorativo a foto da babalorixá Mãe Miriam beijando a bandeira do estado enquanto é observada pelos dois representantes das instituições promotoras do evento, o reitor da UNEAL e o próprio governador do Estado (Figura 1).

Outras duas imagens (Figuras 2 e 3), entre tantas selecionados pela imprensa local para ilustrar a solenidade, reforçam também nosso ponto de vista acerca do protagonismo e do agenciamento do Estado. Na primeira delas (Figura 2), publicada na última página do próprio Diário, intitulada "Xangô Rezado Alto em imagens", aparece o Governador Teotônio Vilela ladeado pelo mesmo Reitor da UNEAL e pela Secretária de Estado da Mulher, da Cidadania e dos Direitos Humanos (SEMCDH), Katia Born. Ambos exibem a Portaria contendo o pedido de perdão enquanto são observados pela mesma mãe de santo e por outros integrantes das comunidades de terreiros situados na parte anterior do palanque, atrás das autoridades convidadas.

\footnotetext{
${ }^{12}$ Para maiores informações sobre a Festa das Águas em Maceió, conferir dos Santos (2014) e Belo (2012).
} 
Figura 1. NO CENTENÁRIO do Quebra DE XANGÔ, O REITOR DA UNEAL, JAIRo CAMPOS,

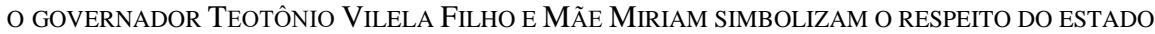
DE ALAGOAS AOS CULTOS AFRO-BRASILEIROS

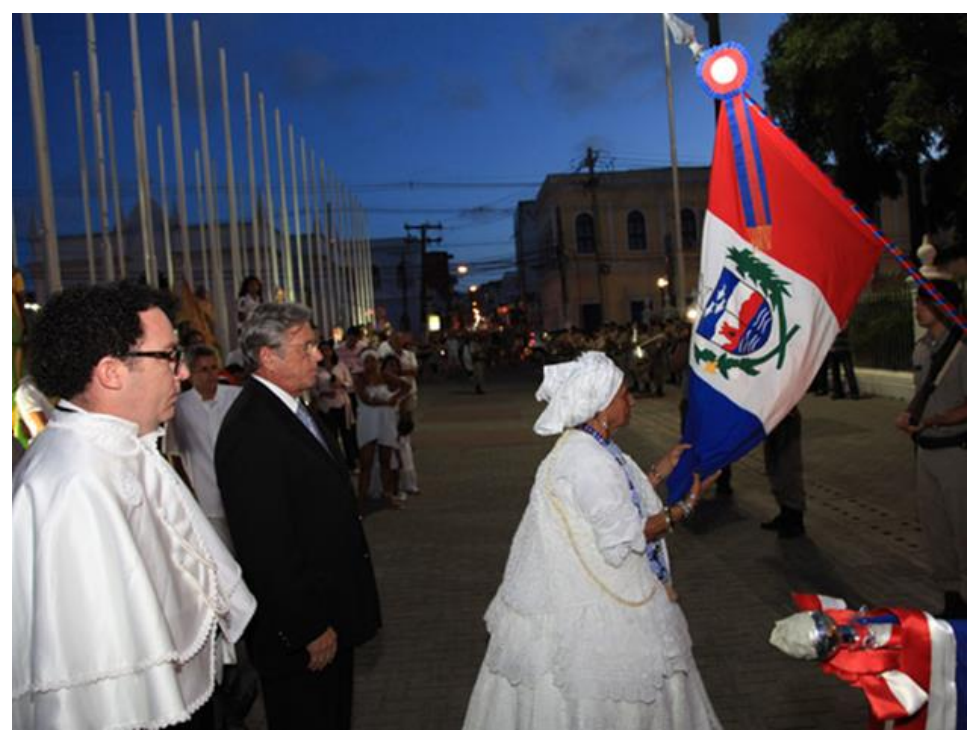

Fonte: Cappello, 2012.

Figura 2. GOVERNADOR TEOTÔNIO VILELA ASSINA DECRETO EM QUE ESTADO PEDE PERDÃo PELOS ATOS DE INTOLERÂNCIA RELIGIOSA

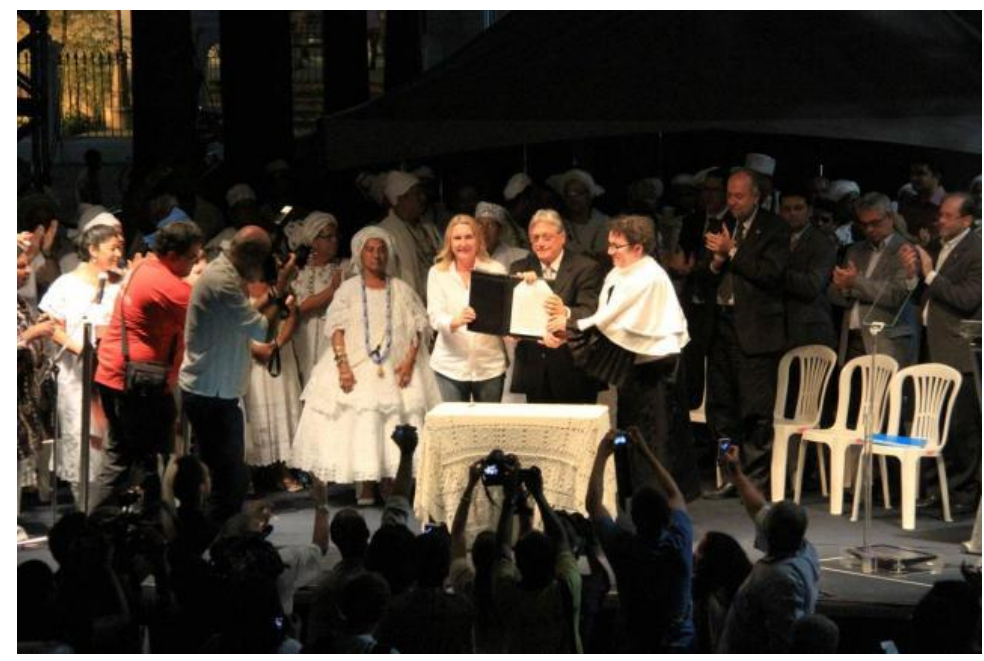

Fonte: Cruz, 2012. 
Figura 3. MÃe MiRiam BEIJA o SOlO DiANTE DE POLICIAIS MILITARES, OBSERVADA POR TEOTÔNIO VILELA, GOVERNADOR DE ALAGOAS
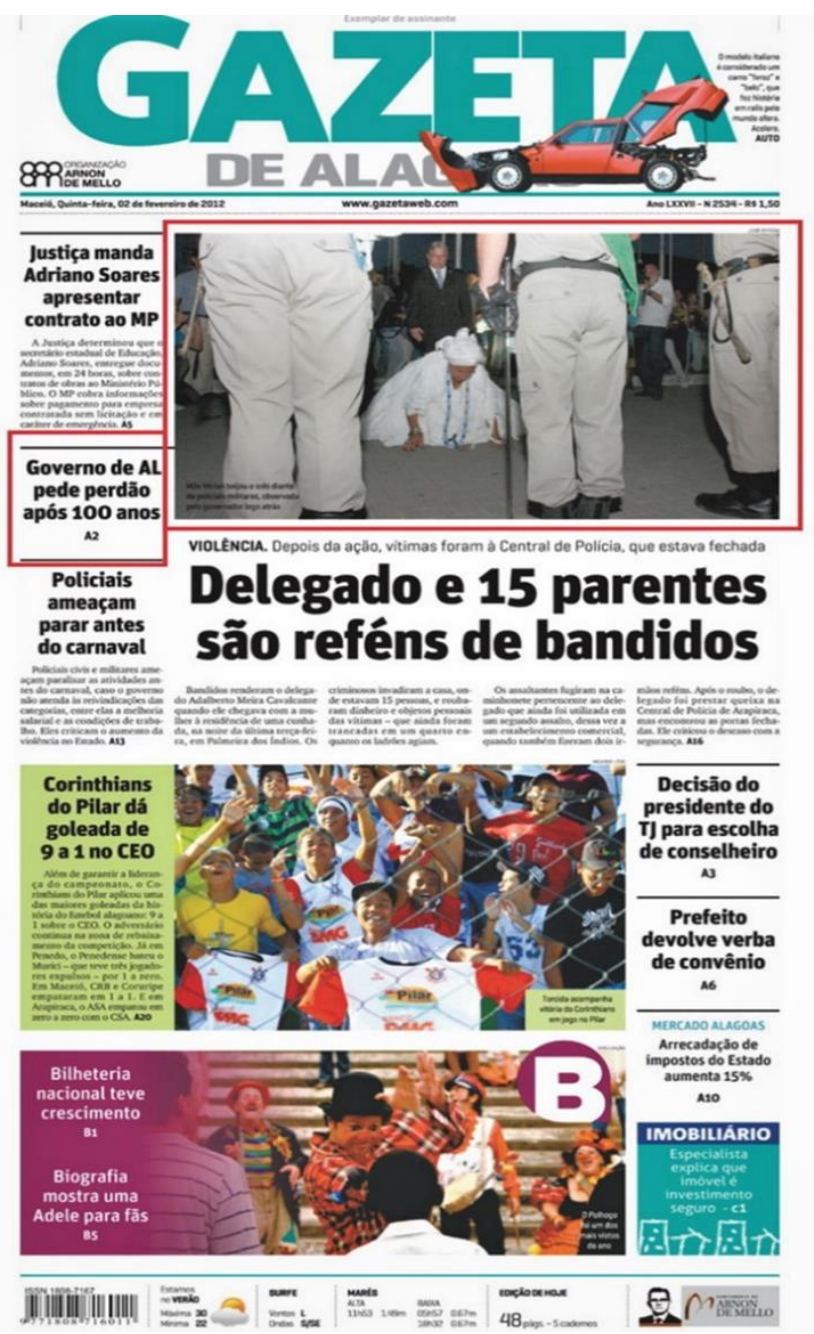

Fonte: Gazeta de Alagoas, 2 de fevereiro de 2012, p. 1.

A última das imagens retrata Mãe Miriam, dessa vez beijando o solo enquanto é observada por policiais (Figura 3), e foi escolhida pela Gazeta de Alagoas para estampar a capa de sua edição do dia 2 de fevereiro. Das três, esta última é a imagem de mais impacto e a que inevitavelmente remete à memória da condição subserviente a que estiveram submetidas as práticas de presença africana em Alagoas depois do Quebra de 1912. 


\section{REFERÊNCIAS}

Barros, F. R. A. (2005). ABC das Alagoas. dicionário biobibliográfico, histórico e geográfico das Alagoas. Senado Federal, Conselho Editorial.

Belo, R. A. (2012). Rastros dos processos educacionais do "Xangô" alagoano. Contribuições para a história da educação [Dissertação de mestrado, Universidade Federal de Alagoas]. Repósitorio Institucional da Ufal. http://www.repositorio.ufal.br/bitstream/riufal/5346/1/Rastros\%20dos\%20processos\%20educacionais\%20do\%20xang\%c3\%b4\%20alagoano$\% 3 a \% 20$ contribui\%c3\%a7\%c3\%b5es\%20para\%20a\%20hist\%c3\%b3ria\%20da\%20educa\%c3\%a7\%c3\%a3o.pdf

Bezerra, E. (2020, 6 de março). O Xangô Rezado Baixo, ou o sentimento de tragédia vivenciado enquanto uma farsa. 082 Noticias. https://082noticias.com/2020/03/06/edson-bezerra/?fbclid=IwAR3qFfUtG3G3KEFQSgtcQzoKOsgtCvIS8Bb-uKvdV_RT0xXJkAr5uC9tlh0

Bruxaria. (1912, 4 de fevereiro). Jornal de Alagoas, p. 1.

Cabral, M. (2012, 2 de fevereiro). Governador assina decreto de perdão pelo Quebra de 1912. Diário Oficial, p. 3.

Cappello, T. (2012, 2 de fevereiro). [Fotografia: no centenário do Quebra de Xangô, o reitor da UNEAL, Jairo Campos, o governador Teotônio Vilela Filho e Mãe Miriam simbolizam o respeito do estado de Alagoas aos cultos afro-brasileiros]. Diário Oficial, p. 1.

Certeau, M. (1994). A invenção do cotidiano. Artes de fazer. Vozes.

Cruz, A. (2 de fevereiro). [Fotografia: governador Teotônio Vilela assina decreto em que estado pede perdão pelos atos de intolerância religiosa]. Diário Oficial, p. 1.

de Sant'Ana, M. M. (1987). História da imprensa em Alagoas, 1831-1981. Arquivo Público de Alagoas.

Decreto $\mathrm{n}^{\circ} 18.041$, de 01 de fevereiro de 2012. Dispõe sobre o pedido formal de perdão pelo Governo do Estado de Alagoas a população afro-alagoana e à religiosidade afro-brasileira devido ao episódio do "Quebra de Xangô de 1912 (2012). http://anajoalagoas.wordpress.com/2012/02/02/decreto-governamentalpedido-de-perdao-ao-quebrade-xango.

do Rio, J. (1906). As religiões do Rio. Garnier.

dos Santos, I. M. F. (2014). "O axé nunca se quebra": transformações históricas em religiões afrobrasileiras, São Paulo e Maceió (1970-2000). Edufal.

Duarte, A. (1974). Catálogo Ilustrado da Coleção Perseverança. DAC; SENEC.

Feitiçaria oficial protetora das oligarquias. (1912, 16 de março). O Malho, p. 38.

Fernandes, G. (1941). Sincretismo Religioso no Brasil. Gauíra.

Fonseca, C. E. S. R. (2020). Arquitetura, Cidade e Rito. Espacializações do sagrado afro-brasileiro em Maceió/AL [Dissertação de mestrado, Universidade Federal de Alagoas]. Repósitorio Institucional da Ufal. http://www.repositorio.ufal.br/bitstream/riufal/7035/3/Arquitetura $\% 2 \mathrm{c} \% 20$ cidade $\% 20 \mathrm{e} \% 20$ rito $\% 3 \mathrm{a} \% 20$ espacializa $\%$ c3\%a7\%c3\%b5es $\% 20 \mathrm{do} \% 20$ sagrado $\% 20$ afro-brasileiro $\% 20 \mathrm{em} \% 20 \mathrm{Macei} \% \mathrm{c} 3 \%$ b3-AL.pdf 
Fry, P., \& Maggie, I. (2006). Apresentação. In Rodrigues, Raimundo Nina. $O$ animismo fetichista dos negros baianos. Editora da UFRJ.

Lima Júnior, F. (2001). Maceió de outrora. Edufal.

Löwy, M. (2011). “A contrapelo”. A concepção dialética da cultura nas teses de Walter Benjamin (1940). Lutas sociais, (25-26), 20-28.

Oliveira, L. (2020, 1 de fevereiro). Xangô rezado alto sai do palco histórico do Quebra. Gazeta de Alagoas. https://d.gazetadealagoas.com.br/caderno-b/248230/xango-rezado-alto-sai-dopalco-historico-do-quebra

Pesavento, S. J. (2008). História, memória e centralidade urbana. Mosaico, 1(1), 3-12. https://doi.org/10.4000/nuevomundo.3212

Prato do dia. (1912, 6 de fevereiro). Jornal de Alagoas, p. 1.

Rafael, U. N. (2012). Xangô rezado baixo. Religião e política na Primeira República. Editora da UFS; EDUFAL.

Rafael, U. N. (2015). A Coleção Perseverança do Instituto Histórico e Geográfico de Alagoas: O papel dos objetos na preservação da memória da violência contra os terreiros de Xangô em Maceió na Primeira República. In A. Gucliemucci \& S. Leal (eds.), Vivir para contarlo. Violencias y memorias en América Latina (pp. 42-51). Papeles del Viento Editores.

Rodrigues, R. N. (2006). O animismo fetichista dos negros baianos. Ministério da Cultura, Fundação Biblioteca Nacional.

Silva, H. R. (2002). "Rememoração"/comemoração: as utilizações sociais da memória. Revista Brasileira de História, 22(44), 425-438. https://doi.org/10.1590/S0102-01882002000200008

Simões, K. (2012, 31 de janeiro). Governo pede perdão oficial pelo Quebra. Diário Oficial, p. 6.

Soares, C., \& Simões, K. (2012, 25 de janeiro). UNEAL celebra a memória do 'Quebra de Xangô' após 100 anos. Diário Oficial, p. 7.

Strathern, P. (2002). Derrida em 90 minutos. Zahar.

Strathern, M. (2013). Fora de contexto: as ficções persuasivas da antropologia. Terceiro Nome.

Trouillot, M. R. (1995). Silencing the Past. Power and the Production of History. Beacon Press.

Turner, V. (1987). The anthropology of performance. PAJ Publications.

Vilela Filho, T. (2012, 2 de fevereiro). Discurso. Diário de Alagoas, p. 6. 